https://doi.org/10.18485/iipe_60nam.2021.ch5

\title{
APPREHENSION, ENGAGEMENT, AND WITHDRAWAL: THE U.S. APPROACH TO COLD WAR NON-ALIGNMENT
}

\author{
Robert B. RAKOVE ${ }^{1}$
}

\begin{abstract}
Although the United States (US) was a traditional practitioner of neutrality, the experience of the two world wars led American Cold War creators to take a sharper approach to non-alignment. This chapter charts Washington's response to non-alignment in the early and middle Cold War years, with special attention to efforts by the Kennedy administration to engage the leading states of the Non-Aligned Movement, particularly at the Belgrade Conference. Despite initial successes in the Kennedy years, the policy of engagement foundered during the presidency of Lyndon Johnson, amid the acrimony of the Vietnam War.

Key words: John F. Kennedy, Lyndon Baines Johnson, Non-alignment, Belgrade Conference

George Kennan, Foreign Aid
\end{abstract}

\section{Introduction}

A stark paradox confronts those considering the often sceptical, sometimes hostile U.S. response to the Non-Aligned Movement (NAM), and the broader phenomenon of non-alignment: the extensive American history of neutrality and outspoken support of neutral rights. Whereas the Cold War-era U.S. administrations often expected and at times demanded solidarity in the global struggle against Soviet communism, their predecessors had celebrated a national tradition of engaging in commerce

\footnotetext{
${ }^{1}$ Lecturer, Stanford University, California, USA.

E-mail: robr@stanford.edu
} 
with all while allying with none. So jarring a transition may seem a generational process, but it could occur with remarkable swiftness, against the backdrop of a global conflagration. Twice, in fact, before the emergence of the Cold War, U.S. administrations pivoted away from neutrality, towards the habitual suspicion of a belligerent power. Although President Woodrow Wilson defended neutral rights for nearly three years, his government's April 1917 entry into the Great War effectively transformed U.S. policy. Alongside its British ally, the United States neutralised powers to limit their trade with the Central Powers. Not even neutral property rights proved sacrosanct; at a stroke in March 1918, London and Washington seized 137 Dutch merchant vessels for their own use. A more tolerant U.S. attitude emerged in 1919 at the Paris peace talks, reinforced by Wilson's failure to achieve ratification of the ensuing treaty and his country's retreat from explicit involvement in European affairs. An almost manic embrace of neutrality on the part of isolationists in the 1930s even entailed the abandonment of previously asserted rights. Foreign observers could be forgiven for believing that the republic had returned to its traditional outlook, but the events of 1917-18 proved more predictive of future conduct (Abbenhuis, 2006, pp. 132-134). Indeed, during the Second World War, the administration of President Franklin Roosevelt sought to terminate neutral commerce with the Axis powers. He and his allies could exert little leverage against neutral powers before the course of the war shifted decisively in favour of the Allies, but once it did, Washington made its preferences plain. Secretary of State Cordell Hull solemnly warned the neutrals in April 1944 against further trade with the Axis; sustained pressure on Sweden and Switzerland followed the June 1944 Normandy landings. Tellingly, the United States tended to deal more severely with the neutrals than did its British ally (Acheson, 1969, p. 55). In this instance, the experience proved formative. Unlike their Wilsonian predecessors, who largely decamped from Washington by 1921, officials who rose to prominence during the Second World War would remain in positions of influence, thereafter carrying a more jaundiced view of neutrality. Thomas Finletter, a future U.S. ambassador to NATO, reflected after the postwar trials of the Nazi leadership: We must, I think, regard Nuremberg as striking down finally the premise of international law that the trade of neutrals with aggressor nations is a right. We may perhaps go even further and assert that now that aggressive war is a crime, it is the positive duty of nations not to be neutral, but to do their fair share in suppressing the criminality (Gabriel, 1988, pp. 64-65). The Second World War conditioned the ascendant policy elite to regard neutrality sceptically: as an expression of timidity or avarice. 
Invocations of traditional rights or protestations of vulnerability to Axis retaliation rang hollow in the ears of combatants engaged in a worldwide struggle. Perhaps a sustained interlude might have allowed this belligerent outlook to recede, but the onset of the Cold War presented Americans with a new global struggle and scant opportunity to reconsider the issue.

\section{The United States and non-alignment in the early Cold War}

To the extent that U.S. policymakers contemplated uncommitted states in the early Cold War years, familiar European neutrals constituted their primary concern. The globalisation of the Cold War by the turn of the 1950s, as well as the ongoing decolonisation of Asia, forced them to contend with an expanding group of states intent on avoiding alignment. Of these, India held singular importance: as a potential counterweight to China, as the largest state in South Asia, and as the most active neutral power at the United Nations. The June 1950 outbreak of the Korean War heightened India's international importance. Prime Minister Jawaharlal Nehru directed his representative at the United Nations to condemn the North Korean invasion but went no further. India abstained from the critical UN resolution asking member states to contribute to the defence of South Korea, and steered an independent course thereafter (McMahon, 1994, pp. 82-86). Nehru had made his views on the Cold War plain to the U.S. government, notably during a visit to Washington the previous year. The Indian prime minister sought geopolitical independence, even as the Cold War divided much of the world into mutually hostile camps. He had declared, in September 1946, "We propose ... to keep away from the power politics of groups aligned against one another, which have led in the past to two world wars, and which may again lead to disasters on an even vaster scale." (Raghavan, 2018, p. 148). Wary of great power entanglements so soon after attaining independence, Nehru also perceived responsibility and opportunity to arbitrate between hostile blocs. His government acted as an indispensable mediator during the Korean conflict: conveying warnings from China to Washington as the UN armies drove north, and subsequently helping to resolve the knotty problem of prisoner of war repatriation (Madan, 2020, pp. 39-46). In the nuclear age, Nehru's aversion to blocs and enthusiasm for mediation had much to commend it, but the Indian experience during the Korean War illustrated abundantly how such a stance would be received by other parties. Even as they sometimes admitted the utility of India's actions, Americans chafed at Indian criticism, ascribing a lack of moral courage to Nehru and his government (Rotter, 2000, pp. 211- 
213). Bitterness lingered after the combatants finally reached an armistice in 1953. "When the chips were down," declared Republican Senator William Knowland afterwards, "India was not there (McMahon, 1994, pp. 179-180)." The Korean War offered divergent lessons to combatants and neutrals alike. To the outgoing Truman administration and its successors, it confirmed the necessity of waging the Cold War on a global basis, of recruiting allies to aid in the struggle. Washington's foremost adversary in the conflict, the People's Republic of China (PRC), derived validation. Success in battling the Western coalition to a standstill affirmed that the PRC stood to play a distinctive role in the spread of revolution in Asia. India, meanwhile, could rightly claim to have been validated: both in its eschewal of alignment and its efforts to mediate the conflict. Henceforth, Washington sought partners, Beijing sought to broaden its international reach, and New Delhi continued to seek a middle course in the Cold War while positioning itself as a leader among the decolonised states. A potential collision loomed: between U.S. pact-building on the one hand; and Indian resistance to the spread of the Cold War and Chinese efforts to diplomatically outflank Washington, on the other. The intersecting agendas of the latter two powers evoked mounting concern from the administration of President Dwight D. Eisenhower. Eisenhower had come to office amid mounting public frustration with his predecessor's conduct of the Korean War, growing anxiety about the broader course of the Cold War, and the demagogic anticommunist campaign of Senator Joseph McCarthy. His secretary of state, John Foster Dulles, lamented that the West appeared to be on the defensive everywhere. A deep concern with the mounting fiscal cost of containment galvanised their search for allies willing to shoulder the burden. Eisenhower and Dulles viewed the Cold War as a stark, moral struggle, but sought to wage it pragmatically. Although Dulles was prone to moments of selfrighteousness, Eisenhower quietly understood that states - particularly those just freed from the shackles of colonialism - might prefer some form of neutrality. Incentives for the affirmation of the right to non-alignment were downplayed due to the feverish political climate of the 1950s and the ongoing pact-building project. Thus, the spectre of the April 1955 AsianAfrican Conference at Bandung Indonesia alarmed U.S. policymakers. The fruit of a five-country initiative, pursued fitfully from the spring of 1954 onward, Bandung presented fretful U.S. policymakers with the spectre of an emerging Asian bloc. China's presence at the conference especially unnerved the Eisenhower administration, which briefly entertained acting in some way to disrupt the gathering. With evident resignation, Dulles concluded that sabotaging Bandung would be counterproductive. To stave 
off the emergence of a Chinese-led Asian bloc, Dulles's government sought to enlist the support of friendly governments (Fraser, 2003, 118-33). A necessary clarification should be tendered at this point: Bandung did not constitute a non-aligned conference. The core organising principle of the meeting, African and Asian solidarity, entailed proffering invitations to states on a geographic basis, without regard for their Cold War alignment. Nevertheless, a substantial, visible core of the Bandung delegations, including the Indonesian host government, espoused a form of Cold War non-alignment, and declarations of regional solidarity stood to undermine the emerging Western network of alliances. Meticulous U.S. preparation for the summit appeared to pay off. Although Nehru and Indonesian President Sukarno offered extensive arguments against Cold War alignment, and China's Zhou En-lai made visible diplomatic inroads, Washington's allies delivered a stalwart defence of their choices to align. No visible bloc, organised along Afro-Asian or non-aligned principles, emerged from the meeting (Parker, 2016, pp. 79-91). Any sense of relief was short-lived. The U.S. alliance-building project had achieved, at best, mixed results by the middle of the decade. The Baghdad Pact and South East Asia Treaty Organisation were shaky imitations of the North Atlantic Treaty Organisation (NATO), which drew scorn from the emerging leadership of the postcolonial world. Egyptian President Gamal Abdel Nasser - another Bandung attendee - criticised the Baghdad Pact for dividing the Arab world and denounced his Iraqi counterpart, a signatory, as an "Anglo-American stooge". U.S. policy towards Egypt in the eighteen months following Bandung amply demonstrated the competing concerns felt by Eisenhower and Dulles in their approach to the non-aligned world. Seeking to capitalize on Nasser's development ambitions, they offered him a loan towards the completion of the Aswan High Dam. The Egyptian leader's recognition of the PRC, acceptance of Czechoslovak-made arms, and rejection of an ArabIsraeli peace plan proposed by Eisenhower suggested bad faith on his part to the White House. Indignant, Eisenhower withdrew the loan offer in July 1956 (Hahn, 1991, pp. 180-210). The news of the loan withdrawal broke hours after Nasser joined Nehru and Yugoslav President Josip Broz Tito on the Dalmatian island of Brioni (a meeting sometimes associated with the inception of organised non-alignment). The Brioni Summit drew little notice from an Eisenhower administration intent on dealing with the separate problems posed by independent-minded leaders like Nasser. Eisenhower and especially Dulles nursed the sentiment that the Egyptian had been ungrateful or, worse, was playing the two blocs off against each other. The previous month, at a university commencement in Iowa, Dulles had termed 
non-alignment an "immoral and shortsighted conception". After reneging on the loan, Dulles asked rhetorically, "Do nations which play both sides get better treatment than nations which are stalwart and work with us?" The answer went without saying. Even as subsequent events - Nasser's nationalization of the Suez Canal, the Anglo-French campaign to recapture the waterway, and Eisenhower's furious efforts to rein in his NATO allies briefly thrust Egypt and the United States into the same corner, the suspicion lingered in Washington. Over the ensuing two years, Eisenhower endeavoured to check the spread of Egyptian influence in the void left by the retreating colonial powers (Lüthi, 2016; Rakove, 2012, pp. 10-12; Yaqub, 2004). Concurrently, he endorsed covert action against the government of Indonesia. In his final year in office, he supported the ouster of Congolese national leader Patrice Lumumba, while the Central Intelligence Agency assisted in Lumumba's apprehension by his enemies and, thus, his murder in early 1961 (Kahin \& Kahin, 1995; Kalb, 1982). The Eisenhower approach to non-alignment can easily appear principally hostile and Manichean: borne of a rigid, ideological conception of the Cold War. Yet, on close inspection, apparent exceptions emerge. The administration set aside anticommunist principles to support Tito's Yugoslavia, which had broken away from the Soviet bloc in the previous decade. Despite the initial friction with Nehru, U.S. economic aid to India grew in both extent and range over the decade. Privately and publicly, Eisenhower spoke of the prudence of neutrality in the Cold War, reflecting that his own country had once adhered to that policy. In the closing years of his administration, he pursued more conciliatory policies toward Egypt and Indonesia. Before the formal emergence of the NAM, U.S. policy struggled to grapple with a diverse, growing caucus of states averse to alignment. The challenge became more complex at the dawn of the following decade, as efforts to organise the nonaligned world attained critical mass (Brands, 1989).

\section{Kennedy's road to Belgrade}

John F. Kennedy ran for office assailing the foreign policies of the Eisenhower administration as outdated, dogmatic, and ineffectual. Denunciation of Eisenhower - and, by extension, his opponent, Vice President Richard M. Nixon - served electoral purposes, to be sure. In the absence of a concrete plan to exercise the civil rights of black voters, and promising a foreign policy that would respond more to the concerns of the new African states, Kennedy appealed to black voters. He thus reaffirmed his concern about waging the Cold War in non-aligned countries. His 
concurrent criticism of Eisenhower policy toward India could not have been tendered with voters in mind. Few American voters in 1960 could have cast their ballots on the basis of policy towards Nehru or Sukarno, and a majority would have been at least sceptical of states professing non-alignment in the Cold War (Meriwether, 2008; Rakove, 2012, pp. 30-32). “We shall not always expect to find them supporting our view," Kennedy noted in his inaugural address, speaking of newly decolonised states, adding: "But we shall always hope to find them strongly supporting their own freedom." As president, he hoped to capitalize on an established record of support for Third World nationalism, cultivated rhetorically, interpersonally, and through acts of legislation. Algerian nationalists celebrated his emphatic and politically hazardous 1957 speech endorsing independence for their country. Guinean President Sekou Touré warmly recalled his 1959 meeting with Kennedy at Disneyland. Indians, meanwhile, could take heart from Kennedy's resolution, submitted with Republican colleague John Sherman Cooper, calling for an increase of aid to India, as well as Kennedy's choice to send prominent economist John Kenneth Galbraith to represent his government in New Delhi (Connelly, 2002, pp. 144-145; Muehlenbeck, 2012, pp. 27-28; Rakove, 2012, p. 29; Siegel, 2020, pp. 221-226). Amid the tumultuous atmosphere of Kennedy's first year, such gestures appeared necessary to stave off, or at least reduce the possibility of conflict between the United States and the leading states of the non-aligned world. Kennedy inherited a world convulsed by chaotic decolonisation and the Cold War conflict. The divided city of Berlin remained a Cold War flashpoint, communist insurgencies wracked South Vietnam and Laos, while the new administration confronted a revolutionary government in Cuba. Other conflicts lacked explicit Cold War valence but could easily become proxy battles between Washington and Moscow. Indonesia sought the cession of the western half of New Guinea, still occupied by the Netherlands. Portugal's determination to retain the colonies in South Asia and southern Africa drew the ire of India and a number of African states. Lastly, most dangerously, Lumumba's death outraged African leaders like Touré and Ghana's Kwame Nkrumah and risked the implosion of the UN peacekeeping mission in the sprawling African country. It also helped to reinvigorate previously dormant efforts by non-aligned states to organise on the international level (Jansen, 1966, pp. 271-277). Until 1961, save during the ambiguous months preceding Bandung, U.S. policymakers had not confronted the possibility of a cohesive non-aligned bloc. They did not relish the prospect. U.S. alliances with European imperial powers had complicated the project of containment since the very beginning of the Cold War. A 
coherent organisation of non-aligned powers, galvanised into existence by anti-colonial sentiment and a shared desire to attain rapid industrialisation, was far more likely to find agreement with the Soviet Union while supporting China's bid for admission into the UN. Yet early signals did not provide cause for alarm. Significant differences separated the outlook of a Nehru, on the one hand, from a Sukarno on the other. While his peers, notably Nasser, Sukarno, and Tito, supported the June 1961 planning conference in Cairo in advance of a non-aligned conference later in the year, Nehru remained wary of creating a new bloc and distrustful of the agendas of his peers. India sent a delegation to the Cairo planning meeting, but its embassy in the Egyptian capital worked to keep U.S. and British diplomats informed about the likely nature of the conference, likely with the goals of informing Western expectations, distinguishing Nehru's government from its peers, and encouraging moderate states to attend (Jansen, 1966, pp. 278290; Rakove, 2014). Inasmuch as they were mutually compatible, India's first two goals proved more attainable than its third. Embassy cables from Cairo reinforced a deep institutional pessimism within the U.S. State Department towards the upcoming non-aligned conference, scheduled for the end of the summer in Belgrade. Senior diplomats, noting that an invitation had been extended to Cuba, took Indian counsel to mean that any effort to influence the upcoming conference was doomed to failure. Despite mounting discontentment among Kennedy's White House staff, the State Department held to this view until the very eve of the Belgrade Conference. Several factors ultimately combined to overturn the "hands off" policy over the summer. A ham-handed effort by the U.S. ambassador in Rio de Janeiro (a holdover from the Eisenhower administration) to preclude Brazilian attendance drew an angry rebuke from President Janio Quadros and gave the broader impression that Washington sought to undermine the conference. A violent July clash between French and Tunisian forces in the vicinity of the French naval base at Bizerte further agitated African and Asian opinion. Lastly, although the ongoing Berlin crisis served to distract President Kennedy in the early summer, the construction of a barrier across the divided city drove JFK to wonder whether the crisis might be employed as a "good propaganda stick" against Moscow across the Third World (Hershberg, 2007; Parker, 2016, pp. 141-148; Rakove, 2012, pp. 69-74). This confluence of events lent momentum to a group of Kennedy's aides as they staged an eleventh-hour effort to overturn the "hands off" policy. Harvard historian and special advisor Arthur Schlesinger Jr succeeded in obtaining JFK's approval to dispatch a special presidential message to the Belgrade Conference attendees. The choice of Soviet General Secretary Nikita 
Khrushchev to resume atomic testing on the very eve of the summit further bolstered the hopes of the Kennedy administration that the summit would yield outcomes favourable to the West. Yet disappointment lay ahead for the Kennedy White House. The ongoing Berlin crisis and Khrushchev's illtimed decision bolstered the hand of non-aligned leaders like Nehru, who wanted the event to address questions of war and peace. Nehru and Nasser each condemned the Soviet decision, but others shied away from the following suit. Hosting the conference, Tito appeared to echo the Soviet position on the German question while excusing Khrushchev's testing resumption. This especially angered U.S. Ambassador George Kennan, whose cables from Belgrade offered the Kennedy administration its main source of information on the conference (Rakove, 2012, pp. 77-80). Kennedy's circumstantial decision to send Kennan to Belgrade, made well before the announcement of the conference, proved both consequential and unfortunate. The choice of the famous diplomat could be understood as a demonstration of Kennedy's concern for his relationship with Yugoslavia. At the best of times, Kennan brought an eloquent pen and a discerning eye to his diplomatic assignments, and his host government could be confident that his cables would be read closely. At his worst, however, Kennan could fall into spasms of emotion that were as intense in expression as they were selective in focus. Well before the conference opened, Kennan showed signs of disaffection and alienation from his host government. A nostalgist who held, at best, disparaging views towards non-European peoples, he was illprepared to listen to a conference that would deal substantially with the evils of the empire. Tito's speech sent Kennan into ill humour from which he did not recover before the conference concluded. He was heard vowing afterwards that he would use his influence to obtain the end of U.S. aid to Yugoslavia (Costigliola, 1997; Rakove, 2014, pp. 13-18). At this Kennan failed, ultimately changing his mind, but his spate of angry cables had their intended effect within the Kennedy White House. Worn down by the Berlin crisis, Kennedy responded to the Belgrade Conference with, by Schlesinger's account, "great and acrid profanity". The mood passed. Nehru had largely succeeded in orienting the conference towards the threat of nuclear war, and as a closing gesture, the attendees dispatched delegations to Washington and Moscow. Kennedy grumbled about receiving Sukarno and Malian President Modibo Keita but proved a receptive and gracious host. A memorandum submitted to him by his advisors Robert Komer and Walt Rostow argued emphatically that those attendees who received U.S. aid had acted with greater moderation, reinforcing Kennedy's earlier inclination to 
engage non-aligned states on a bilateral basis (Rakove, 2012, pp. 80-82; Schlesinger et al., 2007, p. 133).

\section{Engagement after Belgrade (and Kennedy)}

A bilateral emphasis played to Kennedy's strengths: his proficiency at presidential diplomacy; his interest in postcolonial issues; and his commitment to foreign assistance. Throughout his presidency, JFK remained committed to engagement. Interpersonal bonds with non-aligned leaders, ranging from Sukarno and Touré to Tanganyika's President Julius Nyerere, strengthened U.S. relations with non-aligned governments. So, too, did Kennedy's adamant defence of foreign assistance, and the development theories of Walt Rostow, who found a receptive audience in the Third World. Kennedy's willingness, at times, to endorse non-aligned positions in colonial and regional conflicts also earned his government political capital. His support of Congolese integrity and labour leader Cyrille Adoula earned him some credit from African non-aligned leaders. In 1962, he effectively sided with Sukarno against his NATO ally, the Netherlands, over the nettlesome West New Guinea question. The 1961 vote to condemn Portugal for suppressing a revolt in Angola also pleased non-aligned opinion. Yet these stances came at a real cost to existing alliances. "What are the prudent and practical limitations on our traditional view of colonialism?", a weary Secretary of State Dean Rusk wrote. "One or two more Congos - and we've had it." Simultaneously, however, contemplating a recalcitrant Portuguese empire in Africa, and white redoubts in Rhodesia and South Africa, nonaligned states hoped for and expected more (Muehlenbeck, 2012; Noer, 1985, pp. 61-95; Simpson, 2008, pp. 52-61). An upsurge in regional conflicts further complicated Kennedy's efforts. While a cordial relationship with Egypt helped to tamp down Arab-Israeli tensions, Nasser became entangled in a war of counterinsurgency in Yemen. China's autumn 1962 assault on India's northern frontier offered Washington a new opportunity in South Asia, but Pakistani objections to Kennedy's plans to arm India and warming ties between Rawalpindi and Beijing the following year evoked concern and some hesitation in the White House. Kennedy had hoped that Sukarno would focus on domestic matters after his victory in the West New Guinea dispute, but the mercurial Indonesian leader promptly plunged into another dispute: this time against the newly formed federation of Malaysia and its ally, Britain. Congressional foes of foreign assistance, meanwhile, cited all of these emerging conflicts as they staged an unprecedented assault on Kennedy's final foreign aid bill, which remained mired in Congress when 
Kennedy flew to Dallas on November 22, 1963 (David \& Holm, 2016; Jones, 2001, pp. 125-149; Orkaby, 2017, pp. 47-57). Kennedy's assassination in Texas sparked eloquent and profuse expressions of grief across the non-aligned world. His successor, Lyndon Baines Johnson, held no stated objection to engagement as a policy. Facets of engagement could have appealed to LBJ, especially in the realm of foreign aid. He inherited Kennedy's advisory team, which largely remained committed to the policy. Yet other factors gradually inclined Johnson away from the same approach to the non-aligned world. Already preparing an ambitious program of domestic reform, he was wary of the political costs of aiding uncommitted governments. Regional conflicts that had tested Kennedy - in Yemen, Malaysia, and South Asia - worsened visibly in Johnson's early months in office. His own deepening commitment to Vietnam posed a potentially fatal obstacle to the further pursuit of engagement. In the end, however, Johnson's own outlook and temperament made successful implementation of engagement unlikely. He was easily irked by criticism, especially on the part of states receiving U.S. largesse. While his past experience as a Senate majority leader served him well in his approach to the NATO alliance, it left him ill-prepared for the large and growing non-aligned caucus (which had no equivalent on Capitol Hill). Confronting the burdens thrust upon him and the challenges of an election year, LBJ wanted no further complications (McGarr, 2013, pp. 301-344). No single, official act undid a policy that remained fundamentally informal in nature. Key advisors, notably Komer, Chester Bowles, G. Mennen Williams, and Walt Rostow remained committed to tenets of engagement. Yet in the crisis year of 1964, comparably little attention was afforded the second nonaligned conference in Cairo. Johnson dispatched, with apparently no internal objection, a message addressing the attendees. Yet Cairo unfolded in a changed world. Nehru had died earlier in the year, and the addition of a number of African delegations, renewed upheaval in the Congo, and the relative lack of Cold War tensions produced an event with little resemblance to Belgrade. A more militant, anti-colonial tenor emerged from Cairo, which featured more extensive criticism of the United States than had been heard three years earlier. U.S. efforts to dissuade Latin American states from attending the conference contributed to the acrimony. "Here were 44 countries and 11 observers (virtually all recipients of US aid in one form or another) and not a really friendly reference to the US," Komer fumed. Aid was not buying votes - although not for a lack of trying (Rakove, 2012, pp. 192, 220-224). Kennedy had not given aid altruistically, but he had been wary of seeking leverage explicitly or openly. His successor operated by a code of reciprocity that likely made greater sense in a legislative context. Johnson 
proved willing to link further foreign assistance to the foreign and domestic policies of the recipients. At times he proved able to outdo Kennedy in the realm of aid; LBJ's response to the prospect of famine in India was impressive and systematic. The continual use of "short-tether" tactics, however, undermined whatever gains the provision of aid achieved. Advisors noted the risks of recipient backlash, yet Johnson kept his own counsel, and the use of this tactic continued as he committed U.S. troops to the defence of South Vietnam (Ahlberg, 2008, pp. 106-146; Byrne, 2016, pp. 231-244; Engerman, 2018, pp. 227-272). Vietnam proved the final straw. With the exception of Indonesia, which now endorsed an Afro-Asian model of organisation, nonaligned states responded cautiously to Johnson's war. A group of seventeen non-aligned delegations, gathering in Belgrade in March 1965, issued a carefully worded statement calling for immediate negotiations. The Johnson administration, at pains to appear willing to talk, offered rhetorical support to non-aligned countries seeking a diplomatic solution. A pause in the U.S. bombing at the end of 1965 raised hopes in non-aligned capitals, but the resumption of the aerial campaign at the end of the following January suggested the bombing pause had largely been for show (Rakove, 2015). Non-aligned criticism of the United States grew in intensity as Johnson's war continued to escalate. Within the United States, the intense and persistent disapproval of postcolonial states elicited its own backlash, which coincided with a rightward turn in U.S. politics after the election of Richard Nixon. The implosion of Chinese diplomacy within the Third World and the overthrow of more radical governments in Indonesia, Ghana, and Algeria further diminished the perceived need for broad outreach (Brazinsky, 2017, pp. 214230). Although engagement lingered as a periodic impulse for the remainder of the Cold War, pursued at times by Presidents Gerald Ford, Jimmy Carter, and even Ronald Reagan, its heyday had passed. Americans looked with anger or bemused indifference at the NAM which endured, even as it proved too disparate and unwieldy to act with the cohesion desired by its founding generation and was superseded in part by other organisations. Belgrade in 1961 had witnessed the historic intersection of U.S. interest in non-alignment and non-aligned anxiety about the direction of the Cold War. As both sentiments waned, as the NAM pursued a more expansive, less Cold Warcentric agenda, possibilities for mutual comprehension waned. Americans thought little of the NAM when many of the sentiments that undergirded it - opposition to imperialism, fear of war, and pursuit of economic selfsufficiency - should have been readily recognisable. Six decades after Belgrade, reconsideration remains to be achieved. 


\section{References}

Abbenhuis, M. M. (2006). The Art of Staying Neutral: the Netherlands in the First World War, 1914-1918. Amsterdam, Amsterdam University Press.

Acheson, D. (1969). Present at the Creation: My Years in the State Department. New York, Norton.

Ahlberg, K. L. (2008). Transplanting the Great Society: Lyndon Johnson and Food for Peace. Columbia, University of Missouri Press.

Brands, H. W. (1989). The Specter of Neutralism: The United States and the Emergence of the Third World, 1947-1960. New York, Columbia University Press.

Brazinsky, G. (2017). Winning the Third World: Sino-American Rivalry During the Cold War. Chapel Hill, University of North Carolina Press.

Byrne, J. J. (2016). Mecca of Revolution: Algeria, Decolonization, and the Third World Order. New York, Oxford University Press.

Connelly, M. J. (2002). A Diplomatic Revolution: Algeria's Fight for Independence and the Origins of the Post-Cold War Era. New York, Oxford University Press.

Costigliola, F. (1997). "Unceasing Pressure for Penetration": Gender, Pathology, and Emotion in George Kennan's Formation of the Cold War. The Journal of American History, 83, 1309-1339.

David, A., \& Holm, M. (2016). The Kennedy Administration and the Battle Over Foreign Aid: The Untold Story of the Clay Committee. Diplomacy E Statecraft, 27(1), 65-92.

Engerman, D. C. (2018). The Price of Aid. The Economic Cold War in India. Cambridge: Harvard University Press.

Fraser, C (2003). "An American Dilemma: Race and Realpolitik in the American Response to the Bandung Conference, 1955." In Plummer, B. G. (Ed.), Window on Freedom: Race Civil Rights, and Foreign Affairs, 19451988. Chapel Hill, University of North Carolina Press.

Gabriel, J. M. (1988). The American Conception of Neutrality After 1941. New York, St. Martin's Press.

Hahn, P. L. (1991). The United States, Great Britain, and Egypt, 1945-1956: Strategy and Diplomacy in the Early Cold War. Chapel Hill, University of North Carolina Press. 
Hershberg, J. G. (2007). 'High-Spirited Confusion': Brazil, the 1961 Belgrade Non-Aligned Conference, and the Limits of an 'Independent' Foreign Policy During the High Cold War. Cold War History, 7, 373-388.

Jansen, G. H. (1966). Nonalignment and the Afro-Asian States. New York, Praeger.

Jones, M. (2001). Conflict and Confrontation in South East Asia, 1961-1965: Britain, the United States, and the Creation of Malaysia. New York, Cambridge University Press.

Kahin, A., \& Kahin, G. M. (1995). Subversion as Foreign Policy: The Secret Eisenhower and Dulles Debacle in Indonesia. New York, New Press.

Kalb, M. G. (1982). The Congo Cables: The Cold War in Africa - From Eisenhower to Kennedy. New York, Macmillan.

Lüthi, L. M. (2016). Non-Alignment, 1946-1965: Its Establishment and Struggle Against Afro-Asianism. Humanity: An International Journal of Human Rights, Humanitarianism, and Development, 7(2), 201-223.

Madan, T. (2020). Fateful Triangle: How China Shaped U.S.-India Relations During the Cold War. Washington, Brookings Institution Press.

McGarr, P. M. (2013). The Cold War in South Asia: Britain, the United States and the Indian Subcontinent, 1945-1965. New York, Cambridge University Press.

McMahon, R. J. (1994). The Cold War on the Periphery: The United States, India, and Pakistan. New York, Columbia University Press.

Meriwether, J. H. (2008). "Worth a Lot of Negro Votes": Black Voters, Africa, and the 1960 Presidential Campaign. Journal of American History, 95(3), 737-763.

Muehlenbeck, P. E. (2012). Betting on the Africans: John F. Kennedy's Courting of African Nationalist Leaders. New York, Oxford University Press.

Noer, T. J. (1985). Cold War and Black Liberation: The United States and White Rule in Africa, 1948-1968. Columbia, University of Missouri Press.

Orkaby, A. (2017). Beyond the Arab Cold War: The International History of the Yemen Civil War, 1962-68. New York, Oxford University Press.

Parker, J. C. (2016). Hearts, Minds, Voices: U.S. Cold War Public Diplomacy and the Formation of the Third World. New York, Oxford University Press.

Raghavan, S. (2018). Fierce Enigmas: A History of the United States in South Asia. New York, Basic Books. 
Rakove, R. B. (2012). Kennedy, Johnson, and the Nonaligned World. New York, Cambridge University Press.

Rakove, R. B. (2014). Two Roads to Belgrade: The United States, Great Britain, and the First Nonaligned Conference. Cold War History, 14(3), 337-357.

Rakove, R. B. (2015). The Rise and Fall of Non-aligned Mediation, 1961-6. The International History Review, 37(5), 991-1013.

Rotter, A. J. (2000). Comrades at Odds: The United States and India, 1947-1964. Ithaca, Cornell University Press

Schlesinger, A. M. (2007). Journals, 1952-2000. New York, Penguin Press.

Siegel, B. (2020). “The President's Messenger: American Visions, Indian Citizens, and National Development in the Kennedy Years." In C. Schayegh (Ed.), Globalizing the US Presidency: Postcolonial Views of John F. Kennedy. New York, Bloomsbury.

Simpson, B. R. (2008). Economists with Guns: Authoritarian Development and U.S.-Indonesian Relations, 1960-1968. Stanford, Stanford University Press.

Yaqub, S. (2004). Containing Arab Nationalism: the Eisenhower Doctrine and the Middle East. Chapel Hill, University of North Carolina Press. 